\title{
KONSTRUKSI SOSIAL ANGGOTA GENG MOTOR DI KOTA BANDUNG
}

\author{
Purwanti Hadisiwi, Jenny Ratna Suminar \\ Departemen Ilmu Komunikasi, Fakultas Ilmu Komunikasi, Universitas Padjadjaran
}

\begin{abstract}
ABSTRAK
Tujuan penelitian ini adalah untuk mengidentifikasi makna diri anggota geng motor, pengharapan anggota geng motor akan diri yang ideal, dan dinamika pembentukan makna diri geng motor yang meliputi latar belakang komunikasi dengan keluarga, sesama anggota geng motor, dan lingkungan sekitar mereka. Kejahatan geng motor selalu meresahkan masyarakat karena kebrutalannya dalam merusak dan membunuh korban tanpa alasan yang jelas. Pola kejahatannya sama, yaitu dengan mengendarai sepeda motor, mereka merusak dan merampok mini market atau mengejar korban yang tidak bersalah, melukai atau bahkan membunuhnya. Melalui wawancara mendalam terhadap sembilan informan, penelitian ini mencoba membangun realitas geng motor di Kota Bandung. Hasil Penelitian menunjukkan bahwa sebelum bergabung dengan geng motor, mereka melihat dirinya biasa saja, namun setelah bergabung dengan geng motor mereka merasa diri "pang aingna". Anggota geng motor secara kognitif sebenarnya menyadari kalau diri yang ideal adalah menjadi "pemuda baik-baik" seperti yang diharapkan masyarakat. Namun, interaksi dengan teman-teman dalam geng motornya membuat mereka berperilaku "ideal" versi kelompok itu. Selain itu, tidak sepenuhnya benar anggapan tentang anggota geng motor berasal dari keluarga "broken home" namun, komunikasi dalam keluarga memang sangat minim.
\end{abstract}

Kata-kata kunci: Konstruksi sosial, geng motor, makna diri, konsep diri

\section{SOCIAL CONSTRUCTION OF MOTORCYCLE GANG MEMBERS IN BANDUNG}

\begin{abstract}
The purpose of this study is to identify the self meaning of motorcycle gang members, their expectation to become an ideal type, and the dynamics of self-construction and background of a motorcycle gang which includes communication with family, fellow members of the gang, and the environment around them. Motorcycle gang crime is always disturbing for the public, because of their brutality in damaging and killing the victim without any obvious reason. The gangs have a same crime patterns. They ride motorcycles, destroy and rob mini market or chase an innocent victim, injuring or even killing them. Through in-depth interviews with nine informants, the study aims to construct the reality of motorcycle gang members in Bandung. The study showed that prior to become a motorcycle gang member, they see themselves as an ordinary people, but after joining the motorcycle gang they feel themselves as "pang aingna" which means "feeling invicible". Cognitively, motorcycle gang members are aware that the ideal type of self is to become a "good man" as expected by society. However, interaction with friends in their gang make them behave in an "ideal" version self in the group. Moreover, the assumption about the motorcycle gang members come from "broken home" family is not quite right although it reveals the fact that informants have not got a good communication within their own families.
\end{abstract}

Keywords: Social construction, motorcycle gang, self meaning, self concept

Korespondensi: Dr. Hj. Purwanti Hadisiwi, M.Exed, Departemen Ilmu Komunikasi, Fakultas Ilmu Komunikasi Universitas Padjadjaran, Jl. Raya Bandung-Sumedang Km.21. Email: hadisiwi@yahoo.com 


\section{PENDAHULUAN}

Walaupun telah dideklarasikan pembubarannya hampir 3 tahun yang lalu, tepatnya pada akhir Desember 2010, kejahatan geng motor tak pernah benar-benar reda di telinga warga Jawa Barat, terutama Kota Bandung. Geng motor seperti Exalt To Coitus (XTC), Grab On Road (GRB), Brigade Seven (Brigez) dan Moonraker ternyata masih berulah sadis dan brutal. Sejak saat dibubarkan, geng motor ini masih saja melakukan aksi-aksi yang bertentangan dengan hukum.

Awal dari berbagai kejahatan yang dilakukan oleh geng motor adalah pertemuan antargeng yang merupakan saat yang paling rawan gesekan, yang biasanya berujung pada pengambilan harta benda lawan hingga adanya nyawa yang melayang. Gesekan-gesekan ini pada akhirnya melahirkan dendam tak berkesudahan. Yang lebih menakutkan lagi, kejahatan geng motor kian meluas terhadap berbagai hal, mulai dari merampok dan merusak berbagai fasilitas, bahkan membunuh dan merampok masyarakat awam yang mereka temui di jalan. Aksi kejahatan mereka yang semakin membabi buta itulah yang pernah jadi momok warga Bandung untuk keluar pada malam hari.

Dilihat dari sejarah berdirinya, awalnya geng motor hanya kumpulan remaja yang hobi ngebut dengan motor di Kota Bandung. Aksi ini mereka lakukan terutama pada sore, malam, hingga dini hari. Mereka melakukan balapan motor alias trek-trekan di jalanan umum. Tapi dalam perkembangannya, geng motor ternyata begitu meresahkan masyarakat, karena sepak terjangnya makin beringas. Selain itu, kelompok yang berisi remaja-remaja ini terus berkembang dan melebarkan sayap, menyebar ke berbagai wilayah, meski organisasi induknya tetap berada di Kota Bandung, Jawa Barat.

Berdasarkan penyelidikan polisi, ada empat geng terkenal di Kota Bandung, yakni Exalt To Coitus (XTC), Grab On Road (GRB), Brigade Seven (Brigez) dan Moonraker yang pada hakikatnya memiliki 'ideologi' sama, mencetak anggota dari kalangan siswa SMP dan SMA menjadi remaja yang berperilaku sesuai doktrin organisasi mereka. Adapun doktrin itu adalah (1). Anggota harus berani melawan polisi berpangkat komisaris ke bawah; (2). Anggota ha- rus berani melawan orangtuanya sendiri; dan (3). Anggota harus bernyali baja dalam melakukan kejahatan.

Demikian tiga sumpah anggota geng motor di Bandung dalam 'buku putihnya' yang ditemukan polisi pada tahun 1999 (Pos Kota, 2007). Merujuk dari tiga poin doktrin geng motor tersebut, dapat dimaklumi kalau mereka selalu berbuat jahat karena termotivasi doktrin yang ada di kelompoknya itu.

Meski tahu bahwa masuk geng motor bukan hal yang mudah, begitu juga untuk keluar kembali dari sana, namun banyak remaja yang mau menjadi anggota geng motor. Tentu ada beragam sebab yang membuat mereka mau bergabung, namun tak dapat dimungkiri bahwa hal itu tidak terlepas dari cara mereka memandang diri mereka. Dengan kata lain, apa yang mereka lakukan ini tentu tidak terlepas dari konsep diri yang mereka miliki.

Latar belakang hubungan atau komunikasi sebelum menjadi anggota, penggojlokan, hingga komunikasi mereka dengan sesama anggota tentu berkontribusi terhadap pembentukaan konsep diri yang melahirkan perilaku beringas dan kesetiaan yang begitu kuat mereka pada kelompoknya.

Konsep diri merupakan pandangan atas diri sendiri, pengenalan diri sendiri dan pemahaman diri sendiri. Pandangan ini meliputi karakteristik kepribadian dari individu, nilai-nilai kehidupan, prinsip hidup, moralitas, pengalaman dan interaksi individu dengan lingkungan sekitarnya, termasuk komunikasi mereka dengan orang-orang disekitar mereka. Dengan mengetahui konsep diri anggota geng motor yang meliputi citra diri, pengharapan akan diri yang ideal, serta dinamika pembentukan konsep dirinya, diharapkan dapat berkontribusi dalam penanggulangan dan pembinaan anggota geng motor khususnya, dan remaja di Kota Bandung pada umumnya.

\section{METODE PENELITIAN}

Untuk mengungkap konsep diri anggota geng motor ini, digunakan metode penelitian kualitatif dengan tradisi penelitian fenomenologis. Penggunaan metode ini dimaksudkan untuk mengungkap pengalaman sadar menjadi anggota geng motor dengan cara melakukan pen- 
gamatan dan berinteraksi dengan subyek penelitian untuk berusaha memahami bahasa dan tafsiran mereka atas dunianya. Studi dengan pendekatan fenomenologis berupaya menjelaskan makna pengalaman hidup sejumlah orang tentang suatu konsep atau gejala, termasuk di dalamnya konsep diri atau pandangan hidup mereka sendiri. Hal ini seperti dikatakan oleh Cresswell bahwa "a phenomenological study describes the meaning of life experiences for several individuals about a concept or the phenomenon" (Cresswell, 1998: 51).

\section{HASIL DAN PEMBAHASAN}

Penelitian dilakukan terhadap anggota geng motor yang ada di Bandung pada akhir tahun 2010. Informan yang berhasil penulis peroleh berasal dari geng motor Brigez (Brigadir Seven atau sekarang banyak dipelesetkan menjadi Brigadir Setan), XTC, dan GBR

Informan dari Brigez berjumlah lima orang dan seluruhnya masih aktif, bahkan masih tergolong junior. Di antara mereka ada yang pernah ditangkap polisi dan berurusan dengan aparat penegak hukum, namun ada juga yang belum pernah berurusan dengan polisi. Mereka adalah: (1). Her, usia 15 tahun, kelas 1 SMA Mekar Arum Cinunuk, sebelumnya sekolah di STM 5 Bandung, pindah karena dikeluarkan, anak ke-1 dari 2 bersaudara (adik masih SD), Ibu bekerja sebagai PNS, sementara ayah mengurus kebun di Yogyakarta (tidak rutin mengunjungi keluarga di Bandung, yakni antara 1 hingga 3 bulan sekali); (2). Ek, usia 15 tahun, kelas 1 SMA Bandung Timur Cileunyi, pindah dari STM 5 dan mengulang kembali dari kelas 1 karena dikeluarkan, Anak ke-1 dari 2 bersaudara (adik kelas 2 SD), Ayah berkerja di Pindad, Ibu sebagai Ibu Rumah Tangga; (3). Ij, usia 17 tahun, kelas 3 SMA Bandung Timur Cinunuk, anak ke-1 dari 4 bersaudara (adik pertama kelas 1 SMA, adik ke dua kelas 3 SMP, dan adik ke tiga kelas 4 SD), ibu bekerja sebagai pegawai puskesmas, ayah pegawai RS. Al Islam. Ayahnya juga dikenal sebagai ustadz yang aktif memberi ceramah di forum-forum keagamaan di lingkungan tempat tinggalnya. Ayahnya ini juga memiliki dua orang istri; (4). Yo, usia 14 tahun, tidak tamat SMP (dikeluarkan saat kelas 3), anak ke-3 dari 3 bersaudara (dua kakaknya sudah menikah dan bekerja, mereka menetap di Jawa Tengah); dan (5). Fa, Usia 13 tahun, kelas 3 SMP, anak ke-2 dari 2 bersaudara (Kakak sudah kuliah), Ibu adalah ibu rumah tangga, ayah bekerja sebagai PNS)

Sementara itu informan dari geng motor XTC dan GBR sudah senior dan tidak terlalu aktif dalam kegiatan geng mereka, namun masih tercatat sebagai anggota. Mereka adalah: (1). Ki, Usia 17 tahun, putus sekolah (Sempat bersekolah sampai kelas 1 di SMA Pasundan 8); dan (2). Ar, Usia 18 tahun, kelas 3 SMA Kartika Siliwangi.

Sementara itu, ada dua informan lain yang bukan anggota geng motor namun berkontribusi besar pada penelitian ini. Mereka mengetahui seluk beluk informan yang sedang diteliti, hingga bisa memberikan informasi yang diperlukan untuk penelitian ini. Mereka adalah: (1). $\mathrm{Ri}$, Usia 18 tahun, kenal dekat dengan Ki dan $\mathrm{Ar}$ (teman); dan (2). Er, Usia 40 tahun, Kenal dekat dengan informan dari Brigez (tetangga dekat).

Semua informan, meskipun dengan kalimat yang berbeda, menyatakan bahwa tujuan mereka bergabung dengan geng motor (selain karena ketidaktahuan tentang geng motor, pada kasus Ki) adalah untuk mencari teman. Dengan bergabung ke dalam geng, mereka bisa mendapatkan teman sekaligus perlindungan yang membuat mereka merasa aman dan nyaman.

Yo : Ada temen ngajakin. Saya ikut, Seneng karena sama temen-temen sekarang (geng motor) jadi keren, punya seragam (atribut). (wawancara dengan Yo, 10 November 2010)

Fa : Pas punya motor baru. Sama temen pas ada yg punya baru juga, ngajakin gabung sama-sama suka momotoran. Jadi mantap, Bu. (wawancara dengan $\mathrm{Fa}, 11$ November 2010)

Yo dan Fa, serta tiga informan lainnya dari geng motor Brigez serta Ar (XTC) bergabung dengan geng motor karena ajakan teman atau senior yang sudah terlebih dahulu bergabung. Mereka bergabung dengan sadar, meskipun motifnya berbeda. 


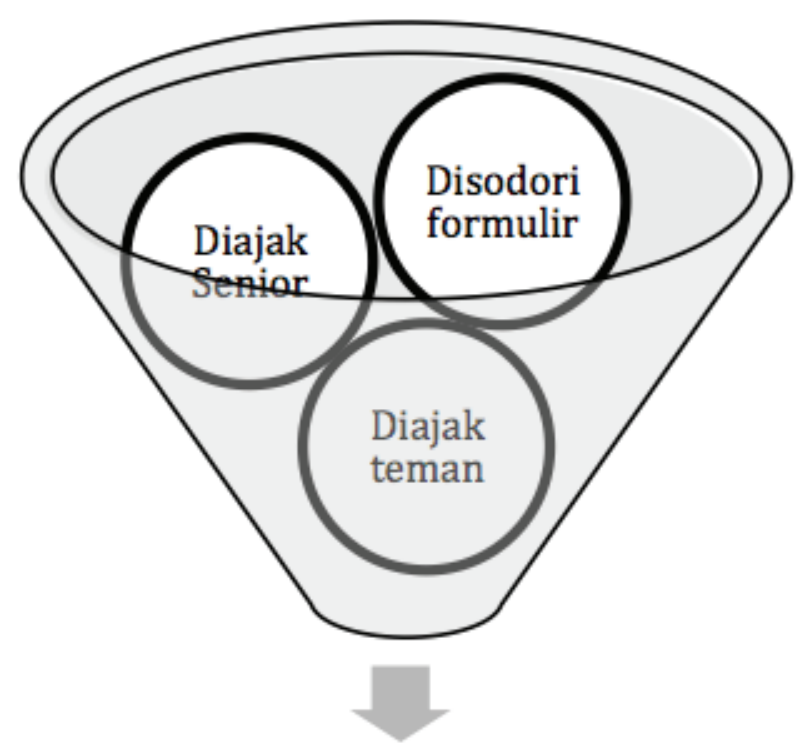

\section{AWAL BERGABUNG DENGAN GENG MOTOR}

Gambar 1 Awal bergabung (cara menjadi anggota) geng motor

Berbeda dengan informan lainnya yang bergabung karena ajakan dan tanpa mengisi formulir keanggotaan resmi, Ki menjadi anggota setelah mengisi sebuah formulir saat pertama masuk SMP. Saat itu geng motor belum seramai sekarang di bicarakan, dia tidak tahu itu perkumpulan apa, yang dia tahu dari seniornya itu adalah kelompok "momotoran". Namun demikian, dia senang berkumpul di sana dan ikut membesarkan geng motor GBR di sekolah tersebut. Hingga atas "prestasinya" itu dia dinobatkan sebagai koordinator di sana.

Menurut Ri dan Ar, anggota geng motor banyak juga orang atau anak orang kaya dan pejabat (ada polisi/anak polisi, pejabat/anak pejabat (menurut Ar ada anggota DPR pusat yang anggota XTC), anak orang "berduit", bahkan anak Ustadz) yang tujuannya bergabung dengan geng motor adalah mencari perlindungan. Orang-orang berduit ini seringkali ditempatkan di posisi-posisi tertentu yang strategis dalam organisasi untuk menjamin keberlangsungan organisasi terutama dari sisi dana operasional.

Nilai-nilai yang didapat di dalam geng motor adalah kebersamaan dan juga loyalitas sesama kawan. Kebersaman ini bisa diartikan positif dan negatif. Hal yang positif adalah rasa setia kawan yang juga berhubungan erat dengan konsep loyalitas yang mereka anut, "senasib sepenanggungan“. Tapi dari situ pula kebersamaan bisa diartikan sebagai hal yang negatif. Aktifitas yang negatif seperti minum minuman keras dan menghisap ganja, mereka lakukan atas dasar kebersamaan. Bahkan untuk urusan perempuan sekalipun, konsep kebersamaan itu pulalah yang mereka pakai. Ar dan Ki mengatakan, jika ada seorang perempuan yang dibawa masuk ke dalam lingkungan geng, itu artinya mereka boleh dan bahkan wajib "dipakai" bersama-sama. Ketika ditanyakan apakah para anggota geng perempuan ini sudah "dipakai", mereka mengatakan "Ya". Peneliti menanyakan lagi dengan lebih jelas: "Jadi bisa dibilang, kalau ada anggota geng perempuan, pasti mereka udah engga perawan lagi?“" mereka menjawab serentak: Ya!““

Selain itu, kebebasan menjadi salah satu alasan mengapa mereka memilih bergabung dengan geng motor. Mereka merasa bahwa mereka memiliki legitimasi untuk bebas melakukan apa saja jika telah bergabung dengan geng motor.

Hal lain yang didapat dari keterlibatan dalam geng adalah perasaan bahwa mereka "jagoan". "Pokona mah kalau udah masuk geng teh asa pang-aingna," begitu istilah mereka. Mereka merasa bisa, berhak, dan berani petantang-petenteng karena punya embel-embel "geng motor XTC/Brigez/GBR” di belakang mereka, 


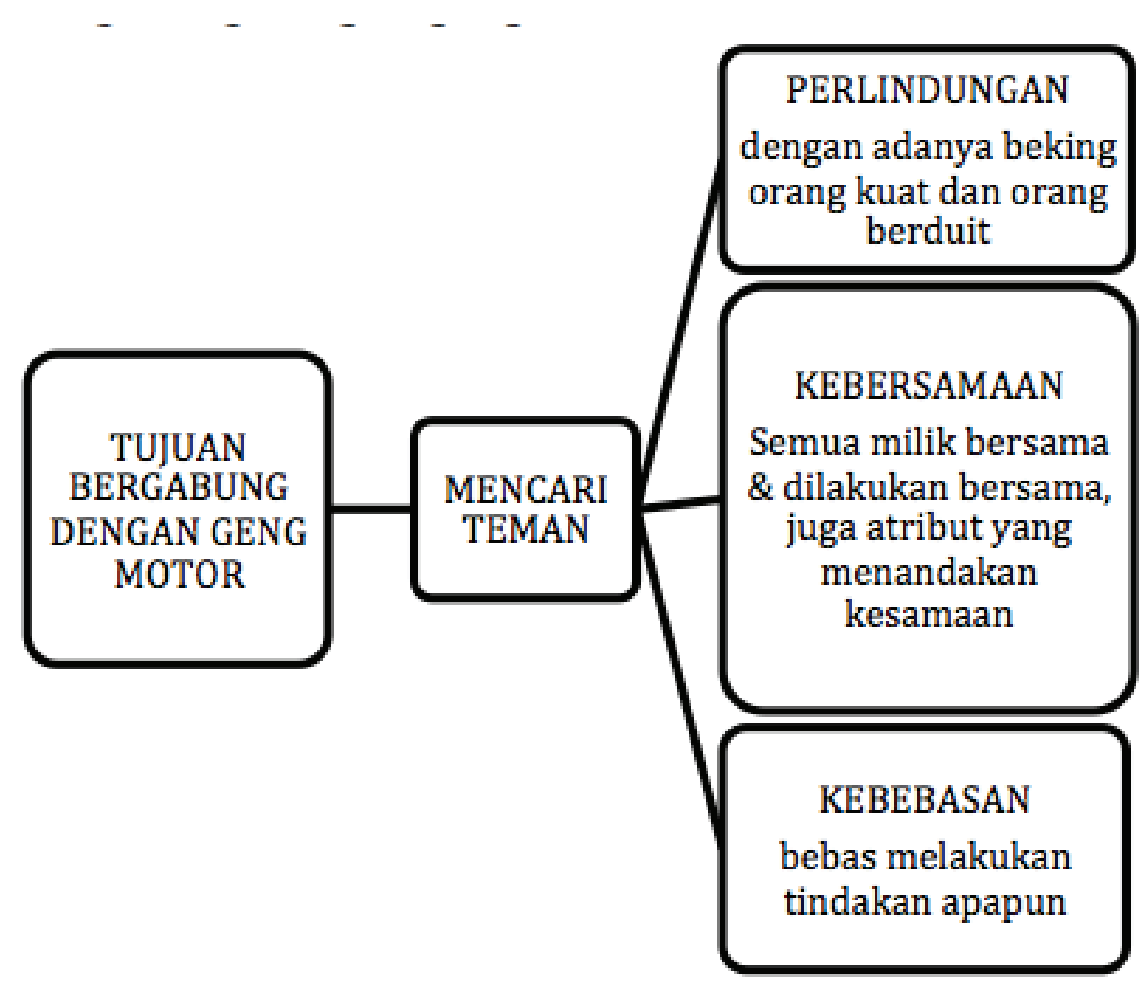

Gambar 2 Tujuan bergabung dengan geng motor

karena mereka merasa punya beking (backing). Walaupun begitu, adakalanya mereka merasa takut jika sedang sendirian.

Citra diri anggota geng motor:

\section{Yo : Saya? Sama saja dengan orang lain. Biasa aja gitu. (wawancara dengan Yo, 10 November 2010) \\ Fa : Gitu aja. \\ Ek : Ya, Gitu. (wawancara dengan Fa dan Ek, 11 November 2010)}

Begitulah jawaban yang diterima peneliti ketika menanyakan kepada informan bagaimana diri mereka ketika dahulu belum bergabung dengan geng motor. Kata "gitu" (begitu) yang mereka pergunakan mengindikasikan bagaimana mereka yang dulu berbeda dengan mereka yang sekarang (gini atau begini). Selain itu, kata gitu juga menyiratkan bagaimana mereka kurang dapat mendeskripsikan seperti apa mereka dulu. Mereka merasa tidak ada yang spesial pada dirinya.

Jawaban ini berbeda dengan ekspresi ketika ditanya seperti apa mereka saat ini. Yo, Fa, Ek, $\mathrm{Ij}$, dan Er menjawab dengan saling menimpali bahwa mereka merasa bangga, gagah, dan mantap. Rasa itu mereka miliki ketika mereka bersama dan mengenakan atribut yang membuat orang lain menoleh dan melihat ke arah mereka. $\mathrm{Ki}$ dan Ar, yang saat ini sudah senior dan tidak terlalu aktif juga menjawab serupa. Saat masih aktif, mereka merasa bahwa mereka adalah orang paling gagah. Dalam kelompok rasanya tidak ada hal yang perlu ditakuti. Seperti yang dikatakan Ki dan Ar "Pokona mah kalau udah masuk geng teh asa pang-aingna,"

Perasaan bangga dan gagah ini, merujuk pada gejala looking-glass self (cermin diri) Charles H. Cooley muncul karena dipengaruhi oleh apa yang mereka yakini tentang pendapat orang lain tentang diri mereka tersebut. Orang-orang yang mereka anggap segan (pada kenyataannya takut) pada mereka, menjadikan mereka merasa gagah dan kuat. Hal seperti itulah yang membuat mereka merasa bangga (Burns, 1993: 17).

Mead berpendapat bahwa konsep diri sebagai obyek timbul didalam interaksi sosial sebagai suatu hasil perkembangan dari perhatian individu tersebut mengenai bagaimana orang lain berinteraksi kepadanya (Burns, 1993: 19). Sebelum bergabung dengan geng motor sebagian anggota geng motor merasa dirinya biasa saja. Tidak ada yang istimewa, meskipun mereka merasa tidak memiliki kekurangan secara fisik. Menurut Er, yang mengenal lima informan Brigez sejak mereka masih kecil, perhatian yang minim dari keluarga dan lingkungan, membuat mereka in- 


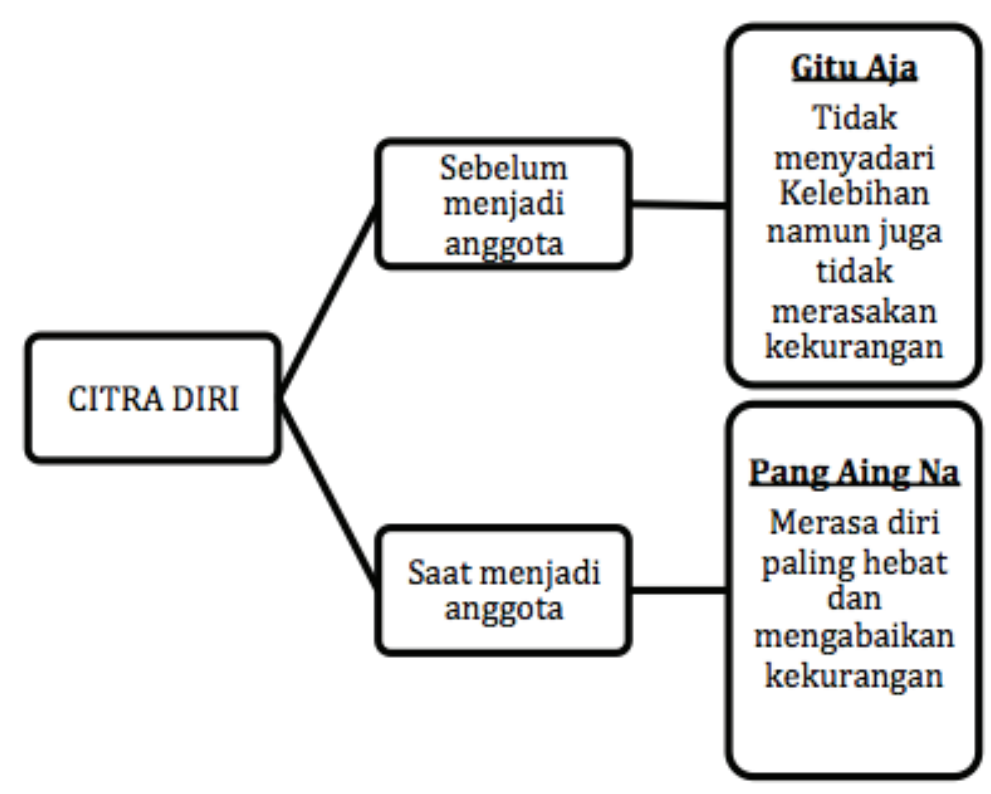

Gambar 3 Citra diri anggota geng motor sebelum dan saat menjadi anggota geng motor

gin terlihat lebih baik. Meskipun memang tidak ada "masalah" dalam keluarga mereka. Dalam artian tak satupun dari mereka berasal dari keluarga "broken home".

Menurut informan, sebagian anggota bergabung dengan geng motor bermula dari inginnya diakui oleh suatu kelompok yang ditandai dengan bolehnya mereka memakai atribut kelompok, bahkan jika sudah melewati masa orientasi mereka bisa mendapatkan kartu anggota. Selain itu, ada pula yang bergabung karena ingin terlihat lebih keren dengan memodifikasi motor mereka menjadi lebih "berani" (misalnya mengganti knalpot motor standar dengan yang lebih berisik, dan lain-lain).

Awalnya semua itu mereka lakukan untuk mengantisipasi reaksi orang lain agar bertingkah laku sesuai ekspektasi mereka, yaitu menilai mereka sebagai orang yang berani, gagah, dan jangan dianggap enteng. Seperti yang dikatakan Yo dan Ij berikut ini:

\section{Ij : Kalo motor dipake sama persis Den gan pas belinya, gak keren.}

Her : Cupu, melempem

Yo : Harus lebih garang biar dihormatin Sama motor (pengemudi motor) lain (wawancara dengan Ij, Her dan Yo, 5 November 2010)

Sebenarnya bila tidak sedang berkumpul beramai-ramai dengan gengnya, anak-anak ini tidak beringas dan "lumayan" bisa diajak ber- komunikasi. Bahkan ketika ditanya tentang sosok diri yang ideal sebetulnya para informan menyadari bahwa bergabung dengan geng motor bukanlah pilihan terbaik dan juga tidak dianjurkan untuk remaja. Hal ini bukanlah kondisi ideal untuk seseorang menghabiskan masa mudanya.

Ki dan Ar yang sudah senior menyatakan jika bisa memilih, mereka lebih senang menghabiskan waktu untuk hal-hal lain yang lebih bermanfaat. Oleh karena itu, saat ini mereka lebih memilih untuk berkonsentrasi mengisi waktu dengan bermain band dan mengisi acara-acara musik (pensi/pentas seni) di berbagai event. Dengan begitu waktu luang yang mereka miliki dapat menghasilkan sesuatu yang bernilai (tinggi).

Namun tidak demikian halnya dengan Yo, $\mathrm{Fa}, \mathrm{Ij}, \mathrm{Her}$, dan Ek yang masih junior. Meski mereka sadar bahwa orang-orang dekat mereka tidak berharap mereka masuk geng motor, mereka tidak punya pilihan. Bukan perkara yang mudah untuk dapat keluar dari geng motor.

Pengharapan mengenai pandangan tentang diri ideal adalah dengan memperoleh jawaban seberapa besar anggota geng motor menyukai diri sendiri. Pengharapan tentang diri ideal juga dengan tentang tentang kemungkinan mereka menjadi apa di masa yang akan datang. Dalam wawancara terhadap lima informan Brigez yang masih junior, terlihat bahwa mereka bingung menjawab diri yang ideal ini. Mereka awalnya terlihat enggan menjawab, meski kemudian ter- 


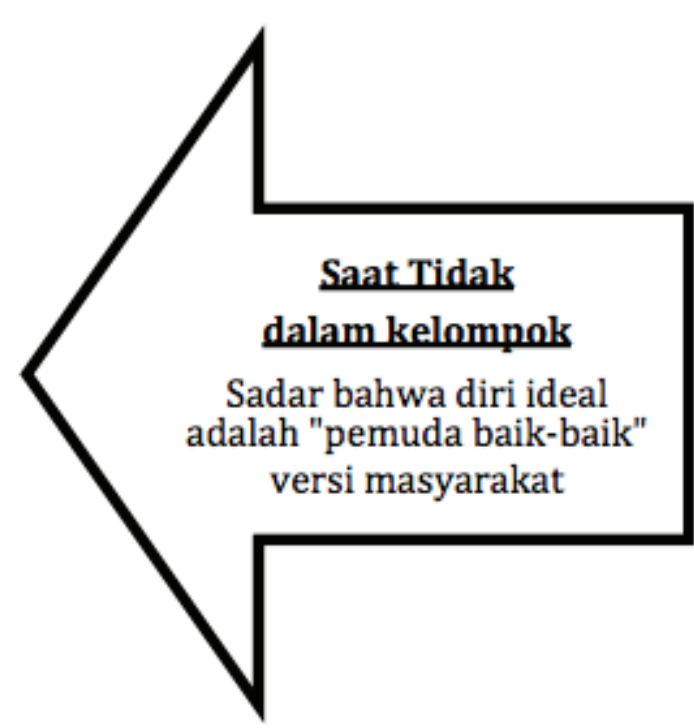

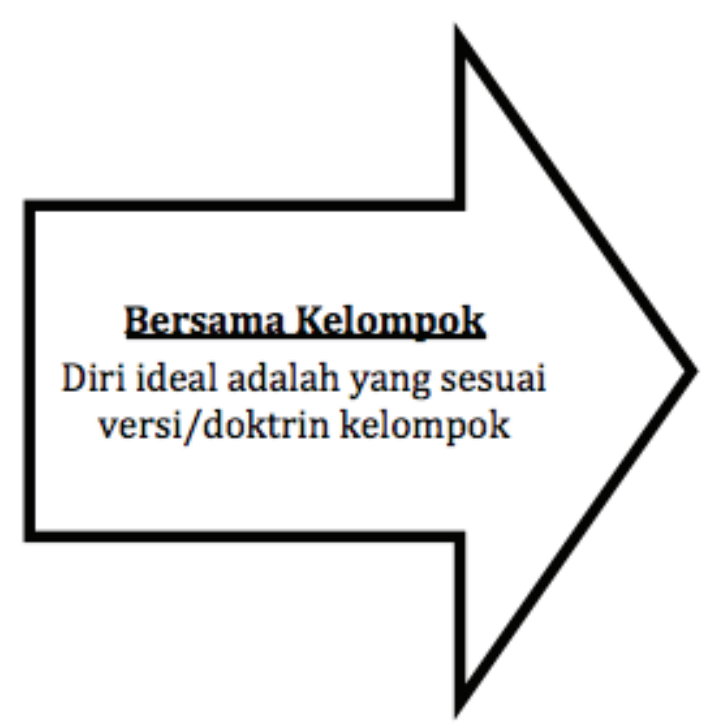

Gambar 4 Pandangan akan diri yang ideal

lontar juga jawaban kalau sosok diri yang ideal adalah "pemuda baik-baik" versi masyarakat.

Berikut ini jawaban-jawaban singkat mereka:

\section{Her : Yang rajin ke masjid mungkin. Tuh jiga si Opik'hahaha. \\ Yo : Anu nurut ka orang tua ya Bu? \\ Ij : Mungkin sekolahnya rajin, ngajinya rajin}

(wawancara dengan Her, Yo dan Ij, 5

November 2010)

Meski mereka menjawab sambil tertawa-tawa, tapi jawaban-jawaban singkat ini menunjukkan bahwa mereka sebenarnya sadar secara kognitif akan sosok ideal yang sebenarnya adalah sosok ideal sesuai yang diinginkan masyarakat. Secara umum sosok yang ideal versi masyarakat tentu yang baik, rajin, menuruti orang tua, dan lain sebagainya.

Namun kesadaran akan sosok ideal ini seperti terhapus begitu saja ketika mereka secara terus menerus berinteraksi dengan teman-teman dalam geng motornya. Teman-teman geng motor itu memang mempunyai pengaruh yang sangat besar pada sikap individu. Hal ini karena kelompok itu mereka rasa mampu menumbuhkan perasaan harga diri, memberikan dukungan,

1 Anak Er, usia 18 tahun, tidak melanjutkan sekolah setelah tamat SMP karena keterbatasan biaya. Saat ini dia membantu perekonomian keluarga dengan bekerja sebagai tukang ojeg, dan kadang-kadang menjadi buruh yang bisa dimintai bantuan oleh warga disekitar rumahnya. Opik juga dikenal sebagai pemuda yang rajin ke masjid dan penurut pada orang tua. kesempatan untuk mempraktekkan dan melatih diri menjadi sosok ideal, sesuai versi kelompok tersebut.

Sesuai versi kelompok, sosok yang ideal adalah yang sesuai dengan doktrin kelompok yakni harus berani melawan polisi, orangtua dan berani melakukan berbagai tindakan yang sebenarnya merupakan kejahatan dan melanggar hukum. Sosok ideal versi kelompok itu ditanamkan dalam diri anggota saat awal mereka bergabung melalui doktrin-doktrin. $\mathrm{t}$

Anggapan bahwa anggota geng itu berasal dari keluarga yang broken home tidak sepenuhnya benar. Ar mengatakan bahwa kedua orangtuanya tidak suka terhadap geng motor. Bahkan ayahnya sangat anti terhadap geng. Yang mengejutkan, Ar mengatakan bahwa ayahnya juga merupakan anggota XTC. Jadi, seorang anggota XTC melarang anaknya untuk ikut-ikutan geng motor, khususnya justru XTC.

Mengapa hal itu terjadi? Ar berujar, bahwa suatu ketika pernah ayahnya dipukuli di tempat kerja oleh rekan kerjanya yang ternyata anggota geng lain yang merupakan musuhnya. Kejadian ini rupanya menyadarkan ayahnya, bahwa menjadi anggota geng mempunyai implikasi yang buruk di kemudian hari, bahkan ketika mereka tidak lagi aktif di kegiatan geng motor dan telah berkeluarga. Hal inilah yang menimbulkan keprihatinan. Menurut Ar, kondisi ini kerap terjadi, ketika seorang anggota geng senior yang sudah tidak aktif dan mempunyai anak istri suatu ketika dianiaya oleh anggota geng 
lain yang menyimpan dendam. "Kan kasian anak-istrinya". komentar Ar. Senada dengan Ar, Ki pun berujar bahwa kedua orangtuanya tidak suka ia terlibat kegiatan geng motor. Jadi selama ini baik Ar dan Ki selalu "susulumputan" kalau ingin kumpul bersama teman-teman geng motornya agar tidak ketahuan keluarganya. "Kalau ketauan pasti dimarahin, lah" kata mereka.

Kondisi Ki dan Ar tidak berbeda jauh dengan yang dialami oleh lima informan junior dari Brigez. Dari mereka berlima selain Ij yang ayahnya mempunyai dua istri, tidak ada satupun keluarga yang "broken home" atau bercerai. Ayah dan ibu mereka masih lengkap. Hanya saja menurut Er, semua ayah mereka terlalu sibuk atau terlalu jauh untuk dapat berkomunikasi secara maksimal dengan keluarga. Sementara itu, ibu-ibu mereka terlalu segan untuk berkomunikasi secara intensif.

Kurangnya komunikasi antara orang tua dengan anak mereka ini terbukti dari ketidaktahuan mereka kalau anaknya terlibat geng motor. Menurut Er, para orang tua anggota geng motor Brigez yang merupakan tetangganya itu baru mengetahui kalau anaknya terlibat geng motor setelah polisi datang menggerebek rumah mereka.

Kurangnya komunikasi orang tua dan anak remajanya ini bisa terjadi karena ayah atau ibu merasa bahwa anak-anak mereka sudah beranjak besar, dan mungkin akan "rese" bila diajak berbincang-bincang, selain bahwa memang kurang adanya i'tikad yang kuat dari para orang tua untuk menyempatkan diri berkomunikasi dengan anak-anaknya. Seperti penuturan Er:

Ibunya teh setengah-setengah Bu kalau nasehatin anaknya. Diomongin (diajak ngobrol) sekali, udah gitu besok-besoknya anaknya gak ditanya-tanya lagi (tidak diajak ngobrol lagi). Jadi weh gak tau kalau anaknya teh masih terus ikutan geng motor.....

Malahan yang ibunya kerja mah gak tau kalau anak-anaknya teh pada bolos sekolah. Pagi-pagi pergi dari rumah pake seragam, padahal itu teh suka pada ada nongkrong dipinggir jalan atau di warung (di lingkungan tempat tinggal mereka). Gak masuk sekolah. (wawancara dengan Er, 1 November 2010)
Yang menarik, 6 (enam) dari 8 (delapan) informan ternyata memiliki pautan usia yang jauh dengan kakak atau adik terdekat mereka. Misalnya Ek yang kelas 1 SMA (seharusnya kelas 2, jika dulu tidak dikeluarkan dari sekolah yang lama) adik satu-satunya baru kelas 2 SD. Demikian pula halnya dengan Yo yang dua orang kakaknya sudah menikah serta sudah memiliki anak dan tinggal di Yogyakarta.

Kakak dan adik mereka yang terpaut usia jauh ini tentunya kurang bisa diajak berkomunikasi untuk berbagai hal. Oleh karena itu mereka merasa membutuhkan teman untuk berbagi, hingga akhirnya mereka terbawa dan merasa "hidup" bersama geng motor.

Kurangnya interaksi dengan keluarga (orang tua dan saudara) membuat para informan kurang mengalami ketergantungan fisik, sosial, maupun emosional pada keluarga. Mereka mencari tempat lainnya yang dapat membuat mereka memiliki ikatan fisik, sosial maupun emosional.

Ketika ditanya, siapa orang yang berpengaruh dalam kehidupan mereka selain temanteman gengnya, Ki dan Ar menjawab serempak. "Orangtua!". Kata Rian "Mau gimanapun kalau pulang ya ke rumah, kalau ada apa-apa ya ke rumah, ke orang tua, " ujar mereka berdua.

Dari sini kita bisa melihat, bahwa sosok orangtua (yang selama ini tidak begitu dekat dengan mereka itu, masih menjadi orangpertama yang sangat berpengaruh terhadap perilaku mereka). Orang lain di luar sesama geng motor dan orang tua, pengaruhnya lebih kecil lagi bagi mereka. Sebenarnya mereka masih "takut" terhadap orangtua mereka. Jadi, doktrin "berani melawan orangtua" yang ditanamkan oleh senior pada mereka yang ternyata sebenarnya tidak sepenuhnya bisa mereka aplikasikan. Mereka tidak bisa "lari" dari orangtua mereka karena masih sangat tergantung. Motor yang mereka miliki pun dibelikan oleh orangtua mereka.

Orangtua memiliki pengaruh yang sangat besar dalam pengembangan konsepsi diri karena orangtua merupakan sumber otoritas dan sumber kepercayaan. Oleh karena itu, seharusnya orangtua merupakan sumber utama dalam memberikan kasih sayang, perhatian, dan penerimaan pada anak-anaknya. Segala hal yang didapatkan dari orangtua akan berpengaruh terhadap pembentukan konsep diri anak. 


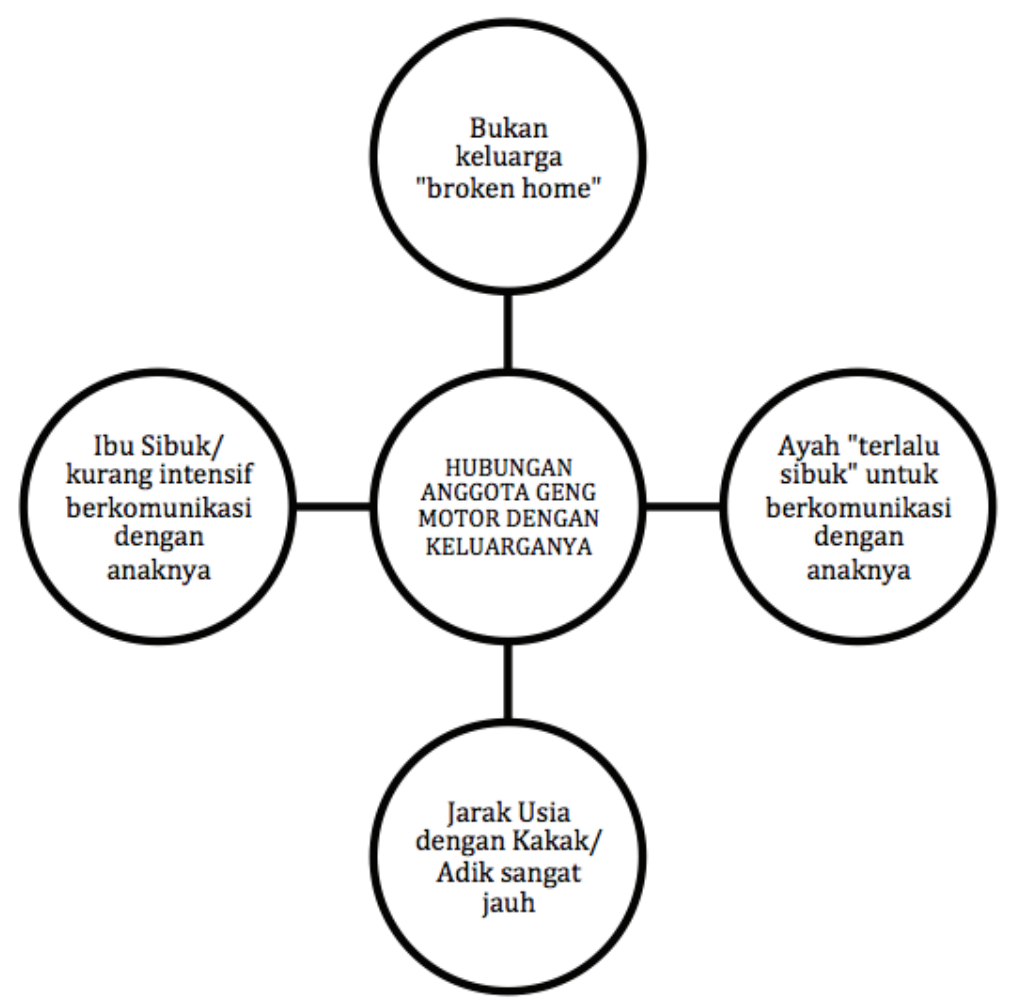

Gambar 5 Hubungan anggota geng motor dengan keluarganya

Kasih sayang dan penerimaan orang tua dapat dirasakan oleh anak-anak melalui isyarat, verbalisasi dan tanda dari orang tua.

\section{SIMPULAN}

Berdasarkan temuan yang telah peneliti uraikan di muka, konsep diri geng motor jelasjelas termasuk ke dalam konsep diri Negatif. Peneliti tanpa ragu memasukkan konsep diri mereka ke dalam kategori ini karena tidak menemukan satupun ciri konsep diri positif, seperti yang dikemukakan para ahli, pada diri mereka. Misalnya, pada anggota geng motor tidak ada tanda-tanda konsep diri positif menurut William dan Phillip (1976) dalam Rakhmat (2004: 105) yang meliputi yakin akan kemampuannya dalam mengatasi masalah, merasa setara dengan orang lain, tidak malu menerima pujian, menyadari bahwa setiap orang mempunyai berbagai perasaan, keinginan dan perilaku yang tidak seluruhnya disetujui masyarakat, mampu memperbaiki dirinya dan sanggup mengungkapkan aspek-aspek kepribadian yang tidak disenanginya dan berusaha mengubahnya, peka terhadap kritik, responsif terhadap pujian, bersikap hiperkritis, merasa tidak disenangi orang lain, dan geng motor enggan bersaing dengan orang lain dalam membuat prestasi yang positif.

Informan penelitian ini sama sekali tidak yakin akan kemampuan mereka sendiri, oleh karena itu mereka mencari teman dan baru merasa mampu saat berada dalam kelompok, yang sayangnya membawa mereka ke jalan yang salah.

Saat berada dalam kelompok mereka merasa diri paling hebat "pang aingna" sementara orang lain atau outsider adalah lebih rendah. Ini terwujud dalam adanya permusuhan "abadi" di antara geng motor tersebut.

Ar dan Ri menceritakan, antara geng motor pada dasarnya saling bermusuhan, tetapi sejarah permusuhan antar geng yang paling lama dan paling besar adalah antara XTC dan Brigez. Kedua geng tersebut memang musuh bebuyutan. Rian menuturkan, sejarah permusuhan antara mereka diawali dari balapan motor. Ketika salah satu ada yang kalah, maka ia dan teman-temannya tidak terima begitu saja. Dimulailah persaingan yang mengarah kepada permusuhan. Tidak jarang perseteruan ini berakhir dengan bentrokan bahkan sampai ada yang meninggal dunia.

Permusuhan itu "terpelihara" sampai sekarang karena dilestarikan oleh para seniornya yang mendoktrin anak buahnya (para junior) bahwa anggota geng tertentu merupakan mu- 
suh besarnya. Ketika ditanya apa yang akan dilakukan jika bertemu dengan anggota geng lain di jalan, Ar dan Ki menjawab, Ya biasa aja sih. Selama merekanya engga ngapa-ngapain, engga ngeganggu kita, ya kita biasa aja. Istilahnya, "Kalau mereka engga jual, kita engga beli“.

Anggota geng motor memang tidak malu menerima pujian, bahkan mengharapkan pujian dengan keberaniannya berlaku brutal. Namun demikian yang sering terjadi adalah salah sangka dalam menerima pujian, mereka justru menganggapnya sebagai bentuk pelecehan

Mereka sebenarnya sadar akan hal ini, sayangnya yang terjadi justru mereka melarikan kekurangan ini dengan cara bergabung dengan geng motor.

Anggota geng motor tidak berusaha mengubah dirinya, kalaupun ada yang ingin mengubah diri dengan keluar dari geng motor, mereka tidak berani melakukannya karena memang agak sulit untuk dapat keluar dari geng motor.

Sementara itu, semua ciri konsep diri negatif nenurut William dan Phillip (1976) dalam Rakhmat (2004: 105) ada pada mereka, yaitu:

Anggota geng motor sangat tidak tahan terhadap kritik yang diterimanya dan mudah marah. Segala koreksi seringkali dipersepsi sebagai usaha untuk menjatuhkan harga dirinya dan geng mereka. Dalam berkomunikasi cenderung menghindari dialog terbuka dan bersikeras mempertahankan pendapatnya, meskipun tidak dengan logika yang benar.

Saat mendapat pujian, individu ini mungkin berpura-pura menghindari pujian, namun tidak dapat menyembunyikan antusiasmenya pada waktu menerima pujian. Buat orang semacam ini, segala macam embel-embel yang menunjang harga dirinya menjadi pusat perhatiannya. Contohnya saja, mereka dengan bangga menggunakan atribut kelompoknya untuk membuat diri mereka bangga.

Sikap hiperkritisnya ditunjukkan dengan selalu mengeluh, mencela atau meremehkan apapun dan pada siapapun.Tidak pandai dan tidak sanggup mengungkapkan penghargaan atau pengakuan pada kelebihan orang lain, apalagi jika mengetahui orang lain tersebut merupakan anggota geng motor lain.

Anggota geng motor mempunyai rasa bahwa dirinya tidak diperhatikan. Oleh karena itu mereka bereaksi pada orang lain sebagai musuh, sehingga tidak dapat melahirkan kehangatan dan keakraban persahabatan. Indvidu ini tidak pernah mempersalahkan dirinya, tetapi akan menganggap dirinya sebagai korban dari sistem sosial yang tidak beres. Dan, sayangnya mereka melarikan diri dengan bergabung ke dalam geng motor.

"Prestasi" yang mereka buat adalah yang negatif. Anggota geng motor menunjukkan "kebesarannya" pada geng motor lain melalui seberapa berani mereka menjarah, seberapa kuat mereka di jalanan, dan lain sebagainya. Mungkin menurut versi geng motor itu "positif" tapi bagi masyarakat ini tentu "negatif"

\section{DAFTAR PUSTAKA}

Burns, R. B. (1993). Konsep diri (teori, pengukuran, perkembangan dan perilaku). Jakarta: Arcan.

Cresswell, J. W. (1998). Qualitative inquiry and research design. London: Sage.

Pos Kota. (2007, 25 Oktober). Disumpah, geng motor berani merampok dan membunuh. Pos Kota [online]. Diakses 12 Agustus 2010 melaluihttp://jawaban.com/forum/ viewtopic.php? $\mathrm{t}=8489 \& \mathrm{sid}=673 \mathrm{bbe} 17 \mathrm{ac}-$ c20cbf5520f8b10bdbcdc1

Rakhmat, J. (2004). Psikologi komunikasi. Bandung: PT. Remaja Rosdakarya Offset. 